\title{
Cytogenetic Studies in Some Species of Passiflora L. (Passifloraceae): A Review Emphasizing Brazilian Species
}

\author{
Margarete Magalhães Souza ${ }^{1 *}$, Telma N. Santana Pereira ${ }^{2}$ and Maria Lúcia Carneiro \\ Vieira $^{3}$ \\ ${ }^{1}$ Universidade Estadual de Santa Cruz - UESC; Departamento de Ciências Biológicas; Rodovia Ilhéus-Itabuna; \\ Km. 16; souzamagg@yahoo.com.br; 45662-000; Ilhéus - BA - Brasil. ${ }^{2}$ Universidade Estadual do Norte Fluminense \\ Darcy Ribeiro - UENF; Centro de Ciências e Tecnologias Agropecuárias; Laboratório de Melhoramento Genético; \\ Campos dos Goytacazes; Rio de Janeiro - RJ - Brasil. ${ }^{3}$ Universidade de São Paulo - USP; Escola Superior de \\ Agricultura "Luiz de Queiroz"; Departamento de Genética; Piracicaba - SP - Brasil
}

\begin{abstract}
The Passifloraceae is represented by species of tropical and subtropical origin. The Passiflora is the richest genus with approximately 450 species, 200 of them being native to Brazil. Recent karyological studies have reported the basic chromosome number for the Passiflora genus as $\mathrm{x}=6$, whereas $\mathrm{x}=9, \mathrm{x}=10$ and $\mathrm{x}=12$ were established as secondary basic numbers. High rates of fertility occur in most Passiflora species, since both meiotic index and pollen viability are above $90 \%$. Unusual meiotic behavior has been described in some taxa. Unviable pollen were observed in some diploids species. The genome size varies from 1.83 to $5.36 \mathrm{pg}$, and significant interspecific variance has been observed. Studies using the FISH methodology have shown that there are two to three rDNA 45S sites and one $5 S$ site in the species analyzed. In this review, information about the above-mentioned studies is presented and discussed in detail.
\end{abstract}

Key words: Karyotype, banding, meiotic behavior, pollen viability, nuclear DNA content, FISH

\section{INTRODUCTION}

The Passifloraceae family contains more than 600 species of tropical and subtropical origin (Vanderplank, 1991). The Passiflora is the richest genus; new species are still being described (McDougal, 2001) and 90\% of them are native to the Americas (Leitão Filho and Aranha, 1974; Lopes, 1991). There is a great inter and intraspecific genetic variability in the Passiflora (Fajardo et al., 1998; Viana et al., 2003; Vieira and Carneiro, 2004) and more than 200 species are natives to Brazilian regions, putting the country in a privileged position in relation to the Passiflora genetic resources (Ferreira, 1994). The Passiflora edulis f. flavicarpa, the yellow passion fruit, is the species of the highest economic importance in the America and the $P$. edulis f. edulis, the purple passion fruit, is marketed in Australia. Brazil and Ecuador are important world producers and consumers. A dozen wild species have edible fruits and are planted in the Latin America, but not widely exploited commercially.

Interspecific crosses were carried out as an alternative for introducing the genes from the wild to the cultivated species. Some sexual hybrids have been obtained in order to increase the ornamental value of the plants (Vanderplank, 1991), to tolerate low temperatures (Knight, 1991), or improved agronomic traits (Knight, 1991;

*Author for correspondence 
Ruberté-Torres and Martin, 1974). Somatic hybrids were also produced to obtain disease or low-temperature resistant plants (Dornelas et al., 1995; Otoni et al., 1995; Barbosa and Vieira, 1997). Self-incompatibility is a somewhat common mechanism in the Passiflora (Payán and Martin, 1975; Rêgo et al., 2001; Souza et al., 2006).

Although Passiflora cytogenetics has been poorly studied and the chromosome numbers fine known for a very few number of species considering the size of the genus, this kind of analysis would be of importance as a contribution to the breeding and evolutionary studies. Nuclear DNA content, meiotic behavior and pollen viability, karyotype establishment and chromosome markers as banding and in situ hybridization are important tools that may be useful to develop the strategies for the germplasm conservation and for understanding the relationships among the Passiflora species. Concerning the breeding, the absolute cytological knowledge cooperates for planning the interspecific hybridizations and also giving the information related to the effect of the individual genome on the hybrid pairing.

\section{Chromosome number and ploidy level}

The chromosome number is known in less than $30 \%$ of the Passiflora species (Soares-Scott et al., 2005). Of around of 200 species that are native to Brazil (Oliveira, 1987), the chromosome number of only a few has been reported (Table 1). The Passiflora species can be divided into four karyological groups, represented by $x=6, x=9, x$ $=10$ and $x=12$ (Melo and Guerra, 2003). The major part presented $2 n=12$ or 18 , but $2 n=14$, $20,22,24,36,72$ and 84 were also found in the native and introduced species. Aneuploidy and polyploidy have been reported as the evolutionary mechanisms (Melo et al., 2001), although most of the Passiflora species are diploid. Cytotypes were described, $P$. misera Kunth with $2 n=12$ and 36, and $P$. suberosa $\mathrm{L}$. with $2 n=12,24,36$. The chromosome number as 22 was reported for $P$. foetida, but according to Melo et al. (2001), this species presented the distended proximal secondary constrictions in prophase and prometaphase that might be confused with two chromosomes leading to wrong interpretation of $2 n=20$. The species presenting $2 n=12$ are considered primitive, or of ancestral Passiflora genus (Stebbins, 1950). Storey (1950) examined different species, interspecific hybrids and polyploid races of the Passiflora and concluded that the basic chromosome number of this genus was $x=3$ or $x=6$. For Darlington and Wylie (1956, quoted by Mehetre and Dahat, 2000), the basic chromosome number was $x=9$. Recent studies suggested that the basic chromosome number of the genus could be $\mathrm{x}_{1}=6$ whereas $x_{2}=$ $9, x_{2}=10$ and $x_{2}=12$ are only secondary basic numbers (Melo et al., 2001; Melo and Guerra, 2003). However, $x=12$ appeared to play an important role in the evolution of the group because it was

better represented in the other genera of the family. In this case, the mechanisms of the chromosome alteration most probably related to these changes would be descending dysploidy ( $x=$ $12 \rightarrow 6$ ) or polyploidy $(x=6 \rightarrow 12)$.

\section{Karyotype studies}

Karyotype analysis of the Passiflora genus has made possible the observation of intra and interspecific variation in the morphology of the chromosomes. The analysis indicated that the number and position of the satellites, secondary constrictions, number and length of chromosomes, and the position of the centromere were probably characteristics of the subgenera and sections (Beal, 1973a, b; Snow and MacDougal, 1993; Mayeda, 1997; Vieira et al., 2004; Table 2). Some authors have observed intraspecific polymorphism, mainly in relation to the satellite number and the location (Oliveira and Coleman, 1996; Mayeda, 1997; Souza et al., 2003c). Mayeda (1997) suggested the presence of two larger pairs of the chromosomes (asymmetric karyotype) and two satellites as the characteristics of the Passiflora genus. However, some species have shown gradual size variation among the chromosomes and only one satellited chromosome pair (Melo et al., 2001; Souza et al., 2003c). According to Melo et al. (2001), the Xerogona, Decaloba and Cieca sections of the Plectostemma subgenus presented very characteristic secondary constrictions (Table 3) and their number and position were the most important karyological features, mainly in the Decaloba section. Basically species presented the metacentric and submetacentric chromosomes, with variable karyotype symmetry (Melo et al., 2001; Beal, 1973a, b; Vieira et al., 1997; Oliveira and Coleman, 1996; Soares-Scott et al., 1999). The subgenus Plectostemma is considered as the most evolved in the Passiflora genera (Mayeda, 1997; Vieira et al., 2004) because it presented more 
asymmetric karyotypes, in agreement with studies related to the plant and herbivore co-evolution (Benson et al., 1975). The chromosome complement length varied significantly from 32.9 to $62.3 \mu \mathrm{m}$ in the species studied (Beal, 1973a, b;
Mayeda, 1997; Souza et al., 2003c; Vieira et al., 2004). Understanding such diversification on genome length is important because it is a significant process during the plant speciation (Greilhuber, 1998).

Table 1 - Chromosome numbers in species of genus Passiflora, occurring in Brazil.

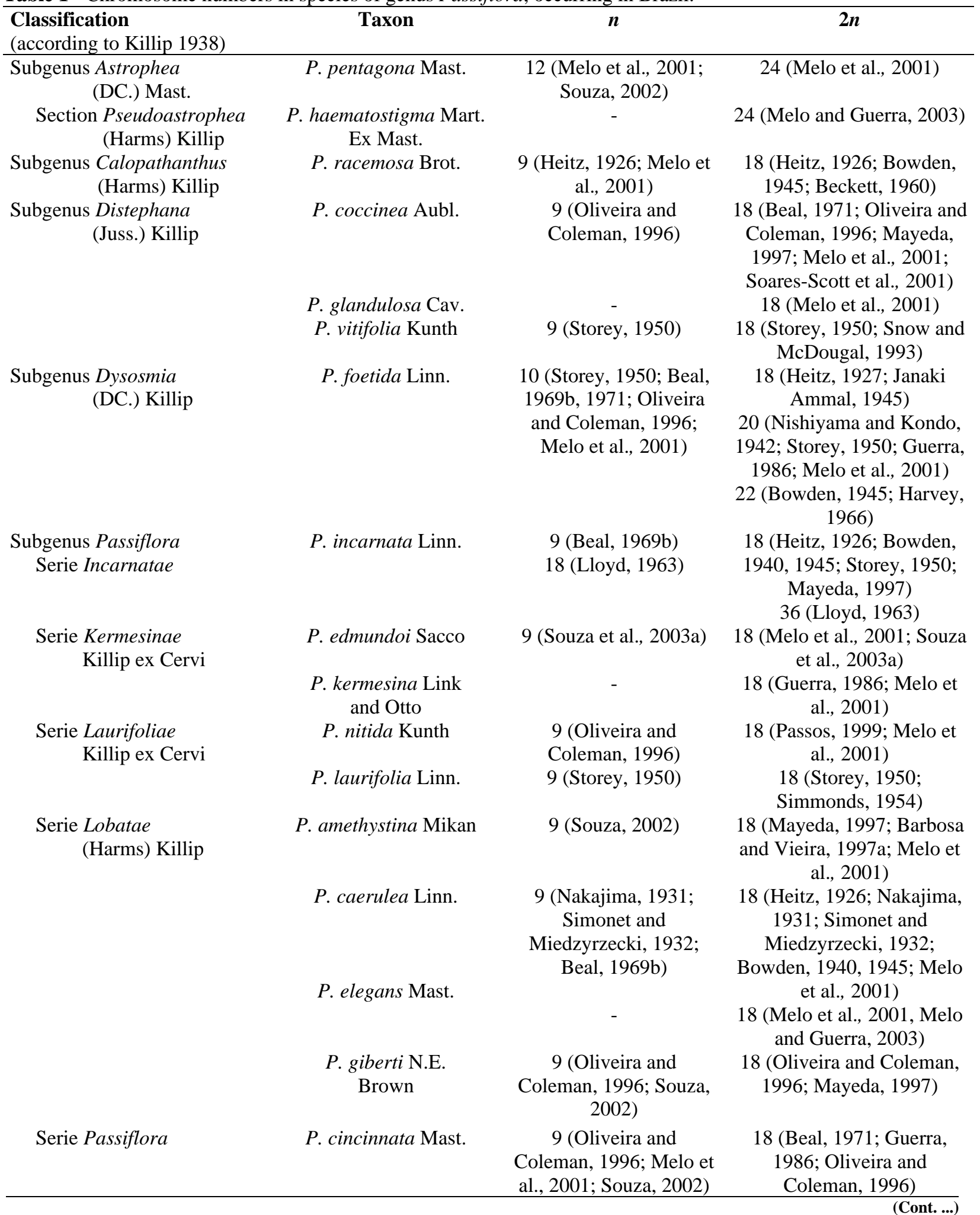




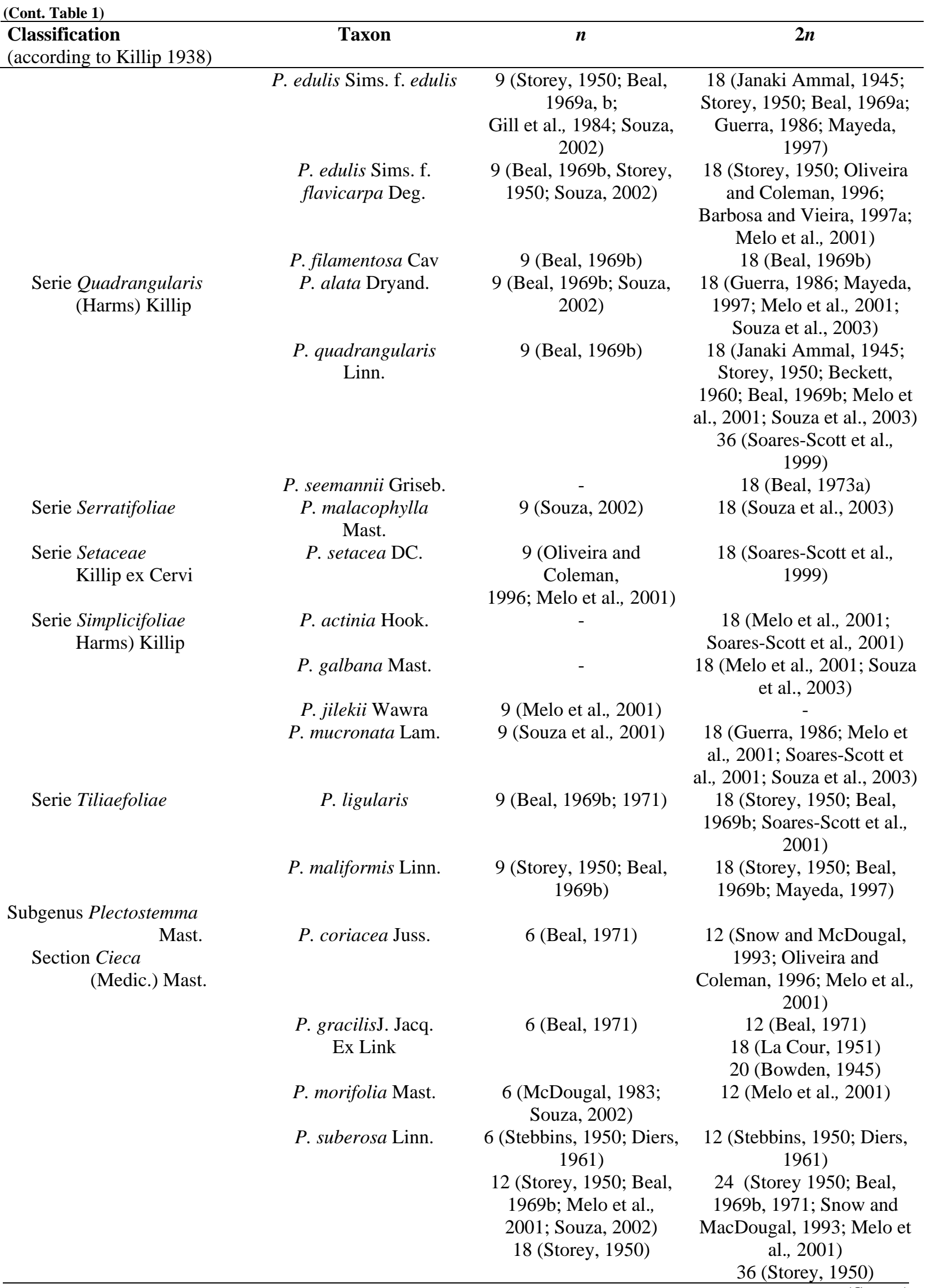


(Cont. Table 1)

\begin{tabular}{|c|c|c|c|}
\hline $\begin{array}{l}\text { Classification } \\
\text { (according to Killip 1938) }\end{array}$ & Taxon & $n$ & $2 n$ \\
\hline \multirow{3}{*}{$\begin{array}{l}\text { Section Decaloba } \\
\text { (DC.) Mast. }\end{array}$} & P. warmingii Masters & 6 (Beal, 1971) & 12 (Beal, 1971) \\
\hline & P. misera Kunth & - & 12, 36 (Melo et al., 2001) \\
\hline & P. tricuspis Mast. & - & 12 (Melo et al., 2001) \\
\hline \multirow[t]{2}{*}{$\begin{array}{l}\text { Section Xerogona } \\
\text { (Raf.) Killip. }\end{array}$} & P. capsularis Linn. & $6($ Souza, 2002$)$ & $\begin{array}{c}12 \text { (Bowden, 1945; Beal, } \\
\text { 1971; Snow and } \\
\text { MacDougal, 1993; Mayeda, } \\
\text { 1997; Melo et al., 2001) }\end{array}$ \\
\hline & P. rubra Linn. & 6 (Souza, 2002) & $\begin{array}{c}12 \text { (Snow and MacDougal, } \\
\text { 1993; Melo et al., 2001) }\end{array}$ \\
\hline
\end{tabular}

Table 2 - Some characteristics of karyotypes and nuclear DNA content (2C) in species of genus Passiflora, occurring in Brazil.

\begin{tabular}{|c|c|c|c|c|c|}
\hline Taxon & LHC & $\mathbf{r}$ & NS /SC & TF (\%) & $\begin{array}{c}\text { Nuclear } \\
\text { DNA content } \\
(p g) \\
\end{array}$ \\
\hline P. coccinea & $\begin{array}{l}18.28 \text { (Oliveira and } \\
\text { Coleman, 1996) } \\
21.39 \text { (Mayeda, } \\
1997)\end{array}$ & - & $\begin{array}{l}3 / 3 \text { (Melo et al., } \\
2001)\end{array}$ & $\begin{array}{l}40.71 \text { (Mayeda, } \\
\text { 1997) }\end{array}$ & - \\
\hline P. incarnata & $\begin{array}{l}18.56 \text { (Mayeda, } \\
\text { 1997) }\end{array}$ & - & $\begin{array}{l}\text { 3/3 (Soares-Scott et } \\
\text { al., 1999) } \\
\text { 1/3 (Mayeda, 1997) }\end{array}$ & $\begin{array}{l}42.26 \text { (Mayeda, } \\
1997)\end{array}$ & - \\
\hline P. edmundoi & $\begin{array}{c}23.96 \text { (Souza } \\
\text { et al., 2003) }\end{array}$ & $\begin{array}{l}1.12 \text { (Souza } \\
\text { et al., 2003) }\end{array}$ & $\begin{array}{l}\text { 1/1 (Souza et al., } \\
2003 \text { ) }\end{array}$ & $\begin{array}{l}46.78 \text { (Souza } \\
\text { et al., 2003) }\end{array}$ & $\begin{array}{l}3.43 \text { (Souza, } \\
2002 \text { ) }\end{array}$ \\
\hline P. kermesina & & & $\begin{array}{l}\text { 3/3 (Melo et al., } \\
\text { 2001) }\end{array}$ & & - \\
\hline P. nitida & - & - & $\begin{array}{l}-/ 3 \text { (Passos, 1999) } \\
\text { 2/2 (Melo et al., } \\
\text { 2001) }\end{array}$ & & $\begin{array}{l}4.82 \\
\text { (Souza et al., } \\
2003 b)\end{array}$ \\
\hline P. laurifolia & - & - & - & - & $\begin{array}{l}3.88 \text { (Souza, } \\
\text { 2002) }\end{array}$ \\
\hline P. amethystina & $\begin{array}{l}21.06 \text { (Mayeda, } \\
\text { 1997) }\end{array}$ & - & 2/2 (Mayeda, 1997) & $\begin{array}{l}43.97 \text { (Mayeda, } \\
\text { 1997) }\end{array}$ & $\begin{array}{l}3.36 \text { (Souza } \\
\text { et al., 2003b) }\end{array}$ \\
\hline P. giberti & $\begin{array}{l}20.01 \text { (Oliveira and } \\
\text { Coleman, 1996) } \\
22.44 \text { (Mayeda, } \\
\text { 1997) }\end{array}$ & - & $\begin{array}{l}\text { 2/2 (Oliveira and } \\
\text { Coleman, 1996; } \\
\text { Mayeda, 1997) }\end{array}$ & $\begin{array}{l}41.91 \text { (Mayeda, } \\
1997) \\
42.46 \text { (Vieira } \\
\text { et al., 2004) }\end{array}$ & $\begin{array}{l}3.92 \text { (Souza, } \\
2002)\end{array}$ \\
\hline P. cincinnata & $\begin{array}{l}25.82 \text { (Oliveira and } \\
\text { Coleman, 1996) }\end{array}$ & - & - & - & - \\
\hline $\begin{array}{l}\text { P. edulis } \mathrm{f} . \\
\text { edulis }\end{array}$ & $\begin{array}{l}19.82 \text { (Mayeda, } \\
\text { 1997) }\end{array}$ & - & 2/2 (Mayeda, 1997) & $\begin{array}{l}44.2 \text { (Mayeda, } \\
\text { 1997) }\end{array}$ & $\begin{array}{l}3.16 \text { (Souza, } \\
2002)\end{array}$ \\
\hline $\begin{array}{l}\text { P. edulis } \mathrm{f} . \\
\text { flavicarpa }\end{array}$ & $\begin{array}{l}19.3 \text { (Oliveira and } \\
\text { Coleman, 1996) } \\
18.8 \text { (Mayeda, } \\
\text { 1997) }\end{array}$ & - & $\begin{array}{l}\text {-/1 (Oliveira and } \\
\text { Coleman, 1996) } \\
\text { 2/2 (Mayeda, 1997) } \\
\text {-/3 Soares-Scott et } \\
\text { al., 1999) }\end{array}$ & $\begin{array}{l}44.9 \text { (Mayeda, } \\
\text { 1997) }\end{array}$ & $\begin{array}{l}3.19-\text { Brazil } \\
3.21-\text { Mexi- } \\
\text { co (Souza, } \\
2002)\end{array}$ \\
\hline
\end{tabular}




\begin{tabular}{|c|c|c|c|c|c|}
\hline Taxon & LHC & $\mathbf{r}$ & NS /SC & TF (\%) & $\begin{array}{c}\text { Nuclear } \\
\text { DNA content } \\
(\mathbf{p g})\end{array}$ \\
\hline P. alata & $\begin{array}{l}22.36 \text { (Mayeda, } \\
\text { 1997) } \\
\text { 22.38 (Souza } \\
\text { et al., 2003) }\end{array}$ & $\begin{array}{l}1.25 \text { (Souza } \\
\text { et al., 2003) }\end{array}$ & $\begin{array}{l}\text { 2/2 (Mayeda, 1997) } \\
\text { 2/2 (Melo et al., } \\
\text { 2001) } \\
\text { 3/3 (Souza et al., } \\
\text { 2003) }\end{array}$ & $\begin{array}{l}42.82 \text { (Mayeda, } \\
1997 \text { ) } \\
45.3 \text { (Souza } \\
\text { et al., 2003) }\end{array}$ & - \\
\hline P. quadrangularis & $\begin{array}{l}62.8 *(\text { Beal, 1973a) } \\
33.58 \text { (Souza } \\
\text { et al., 2003) }\end{array}$ & $\begin{array}{l}1.5 \text { (Beal, } \\
1973 \mathrm{a}) \\
1.59 \text { (Souza } \\
\text { et al., 2003) }\end{array}$ & $\begin{array}{l}\text { 6/6 (Beal, 1973a) } \\
\text { 2/2 (Souza } \\
\text { et al., 2003) }\end{array}$ & $\begin{array}{l}38.68 \text { (Souza } \\
\text { et al., 2003) }\end{array}$ & $\begin{array}{l}5.36 \text { (Souza, } \\
2002)\end{array}$ \\
\hline P. seemannii & $\begin{array}{l}55.9-66.9 \\
(\text { Beal, 1973a) }\end{array}$ & - & - & - & - \\
\hline P. malacophylla & $\begin{array}{l}14.67 \text { (Souza } \\
\text { et al., 2003) }\end{array}$ & $\begin{array}{l}1.37 \text { (Souza } \\
\text { et al., 2003) }\end{array}$ & $\begin{array}{l}1 / 1 \text { (Souza } \\
\text { et al., 2003) }\end{array}$ & $\begin{array}{l}43.42 \text { (Souza } \\
\text { et al., 2003) }\end{array}$ & - \\
\hline P. galbana & $\begin{array}{l}17.9 \text { (Souza } \\
\text { et al., 2003) }\end{array}$ & $\begin{array}{l}1.24 \text { (Souza } \\
\text { et al., 2003) }\end{array}$ & $\begin{array}{l}2 / 2 \text { (Souza } \\
\text { et al., 2003) }\end{array}$ & $\begin{array}{l}44.41 \text { (Souza } \\
\text { et al., 2003) }\end{array}$ & $\begin{array}{l}3.52 \text { (Souza } \\
\text { et al., 2003b) }\end{array}$ \\
\hline P. mucronata & $\begin{array}{l}22.54 \text { (Souza } \\
\text { et al., 2003) }\end{array}$ & $\begin{array}{l}1.38 \text { (Souza } \\
\text { et al., 2003) }\end{array}$ & $\begin{array}{l}\text { 2/2 (Melo et al., } \\
\text { 2001; Souza } \\
\text { et al., 2003) }\end{array}$ & $\begin{array}{l}42.01 \text { (Souza } \\
\text { et al., 2003) }\end{array}$ & $\begin{array}{l}3.4 \text { (Souza, } \\
2002)\end{array}$ \\
\hline P. maliformis & $\begin{array}{l}55.9 *(\text { Beal, 1973a) } \\
22.54 \text { (Mayeda, } \\
1997) \\
21.20 \text { (Vieira } \\
\text { et al., 2004) }\end{array}$ & $\begin{array}{l}1.2(\text { Beal, } \\
1973 \mathrm{a}) \\
-\end{array}$ & $\begin{array}{l}\text { 4/4 (Beal, 1973a) } \\
\text { 2/2 (Mayeda, 1997) } \\
-\end{array}$ & $\begin{array}{l}46.21 \text { (Mayeda, } \\
\text { 1997) } \\
46.22 \text { (Vieira } \\
\text { et al., 2004) }\end{array}$ & $\begin{array}{l}3.78 \text { (Souza } \\
\text { et al., 2003b) }\end{array}$ \\
\hline P. morifolia & $\begin{array}{l}13.43 \text { (Melo } \\
\text { et al., 2001) }\end{array}$ & $\begin{array}{l}1.72 \text { (Melo } \\
\text { et al., 2001) }\end{array}$ & $\begin{array}{l}\text { 1/1 (Melo } \\
\text { et al., 2001) }\end{array}$ & - & - \\
\hline P. suberosa & $55.1 *($ Beal, 1973a) & $\begin{array}{l}1.3 \text { (Beal, } \\
1973 \mathrm{a})\end{array}$ & 5/5 (Beal, 1973b) & - & $\begin{array}{l}1.85 \text { (Souza, } \\
2002 \text { ) }\end{array}$ \\
\hline P. misera & $\begin{array}{l}9.93 \text { (Melo } \\
\text { et al., 2001) }\end{array}$ & $\begin{array}{l}1.87 \text { (Melo } \\
\text { et al., 2001) }\end{array}$ & $\begin{array}{l}\text { 1/1 (Melo } \\
\text { et al., 2001) }\end{array}$ & - & - \\
\hline P. tricuspis & $\begin{array}{l}10.89 \text { (Melo } \\
\text { et al., 2001) }\end{array}$ & $\begin{array}{l}1.67 \text { (Melo } \\
\text { et al., 2001) }\end{array}$ & $\begin{array}{l}\text { 1/1 (Melo } \\
\text { et al., 2001) }\end{array}$ & - & - \\
\hline P. capsularis & $\begin{array}{l}8.03 \text { (Mayeda, } \\
\text { 1997) }\end{array}$ & - & $\begin{array}{l}\text { 1/1 (Snow and } \\
\text { MacDougal, 1993) } \\
\text { 1/2 (Mayeda } \\
\text { et al., 1997) }\end{array}$ & $\begin{array}{l}39.55 \text { (Mayeda, } \\
1997)\end{array}$ & - \\
\hline
\end{tabular}

*Total chromosome length in the complement (Beal, 1973a). LHC = length of haploid complement; $r=$ ratio of length of long arms to length of short arms; NS/CS = number of satellites/secondary constrictions; TF $(\%)=$ asymmetry index or index total form percent (TF\%; Huziwara, 1962). 
Table 3 - Karyological features in subgenus of Passiflora.

\begin{tabular}{|c|c|c|c|}
\hline \multirow[b]{3}{*}{ Authors } & \multicolumn{3}{|c|}{ Subgenus Plectostemma } \\
\hline & \multicolumn{3}{|c|}{ Sections } \\
\hline & Xerogona & Decaloba & Cieca \\
\hline Melo et al., 2001 & $\begin{array}{l}\text { SC in the terminal region of the } \\
\text { largest chromosome pair. } \\
\text { Observed } \\
\text { in } P . \text { capsularis and } P . \text { rubra. }\end{array}$ & $\begin{array}{l}\text { SC in the proximal region of } \\
\text { the } \\
\text { One of the smallest } \\
\text { chromosome pairs*. } \\
\text { Observed in } P \text {. misera and } P \text {. } \\
\text { tricuspis. }\end{array}$ & $\begin{array}{l}\text { SC in the terminal region of } \\
\text { the smallest chromosome } \\
\text { pair. Observed in } P \text {. } \\
\text { morifolia. }\end{array}$ \\
\hline Mayeda, 1997 & $\begin{array}{l}\text { Two SC in the largest } \\
\text { chromosome pairs and only one } \\
\text { pair satellited. Observed in } P \text {. } \\
\text { capsularis. }\end{array}$ & - & - \\
\hline & Subgenus Passiflora & Subgenus Distephana & Subgenus Tacsonia \\
\hline $\begin{array}{l}\text { Mayeda, 1997; } \\
\text { Vieira et al., } 2003\end{array}$ & $\begin{array}{l}\text { Two pairs of largest } \\
\text { chromosomes, being the } \\
\text { chromosome } 1 \text { submetacentric } \\
\text { and } 2 \text { metacentric. } \\
\text { SC and satellites on two } \\
\text { smallest } \\
\text { pairs. Observed in P. alata, } P \text {. } \\
\text { edulis, } P \text {. amethystina, } P \text {. } \\
\text { giberti. }\end{array}$ & $\begin{array}{l}\text { Chromosome } 1 \\
\text { submetacentric } \\
\text { And } 2 \text { metacentric. Observed } \\
\text { in } P \text {. coccinea. }\end{array}$ & $\begin{array}{l}\text { SC in three chromosome } \\
\text { pairs. Observed in } P . \\
\text { molissima**. }\end{array}$ \\
\hline Passos, 1999 & $\begin{array}{l}\text { SC on three chromosome pairs. } \\
\text { Observed in } P \text {. nitida. }\end{array}$ & & \\
\hline
\end{tabular}

\section{Banding and in situ hybridization}

Banding pattern studies have been performed using stains with affinity for A-T or C-G bases (Melo et al., 2001) and with silver to stain the nucleolus organizer region (Mayeda, 1997). Howeverk $(\square \mathrm{sw}$ species have been included in these studies, which allow the individual classification of the chromosomes and the analysis of the genomic relationships among the related species. The studies involving Ag-NOR banding, where only active NORs were specifically detectable (Scwarzacher et al., 1980), were performed in $P$. alata, $P$. amethystina, $P$. coccinea, $P$. edulis f. flavicarpa, $P$. incarnata and $P$. maliformis. In some species, there was more than one pair of the chromosomes carrier of the nucleolus organizer region, as in $P$. coccinea (Mayeda, 1997; Vieira et al., 2004). The CMADAPI banding was performed on eight species, $P$. amethystina, $P$. caerulea, $P$. capsularis, $P$. edulis f. edulis, $P$. foetida, $P$. racemosa, $P$. rubra and $P$. tricuspis. These species showed from one to three pairs of the $\mathrm{CMA}^{+}$blocks but did not present the
$\mathrm{DAPI}^{+}$heterocromatin. The $\mathrm{CMA}^{+}$block positions were in agreement with the morphological features observed on the chromosome pairs in relation to the presence of the secondary constrictions (Melo et al., 2001) and with both the number and position of the 45S rDNA sites detected by the FISH. On the other hand, the number of 5S rDNA sites did not correlate with any other cytological parameter (Melo and Guerra 2003).

The studies aiming at the mapping of the $45 \mathrm{~S}$ rDNA showed the presence of secondary constrictions and satellites associated to the chromosomes 8 and 9 in $P$. edulis f. edulis, with four sites, and $P$. amethystina, with six sites. Both the species were used as the parental, and the somatic hybrid presented two sites more than both the parental (Cuco et al., 2001). Melo and Guerra (2003) analyzed the variation on $5 \mathrm{~S}$ and $45 \mathrm{~S}$ rDNA sites in 20 Passiflora species (21 taxons) and observed that the diploid species with $x=6$, in general, presented only two $5 \mathrm{~S}$ sites and two or four $45 \mathrm{~S}$ rDNA sites, which were clearly related to the ploidy level, while others species with $x=9$ 
and $x=10$ frequently displayed more than two sites of the 45S and 5S rDNA. According to these authors, in general, the number and localization of 5S and 45S rDNA sites were consistent with the hypothesis of $x=6$, originally diploid, as the probable ancestral genome for the genus, while the group of species with $x=9, x=10$ and $x=12$ were considered to be of tetraploid origin with descending dysploidy $(12 \rightarrow 10 \rightarrow 9)$, and reduction (gene silencing) of some redundant sites, mainly those of $5 \mathrm{~S}$ rDNA.

\section{Meiotic behavior and pollen viability}

Meiotic studies performed on the cultivated and wild Passiflora species indicated meiotic stability (Barbosa and Vieira 1997a, b; Melo et al., 2001; Souza, 2002; Souza et al., 2003a). The species with $2 n=18$, in general, presented regular meiosis and high fertility (Ferreira, 1994). Some species with $2 n=24, P$. pentagona and $P$. suberosa, presented unusual meiotic behavior; many irregularities were observed that could lead these species to a meiotic index below 90\% (Souza, 2002). The laggard chromosomes, anaphase bridges (Barbosa and Vieira, 1997b; Souza, 2002), non-oriented segregation at metaphase and anaphase I (Souza et al., 1996), spindle orientation abnormalities and asynchronism were the most common irregularities observed, and consequently, anomalous post-meiotic products as monads, dyads, triads and polyads were formed (Souza, 2002; Souza et al.; 2003a). The species displayed bivalents as the predominant chromosome associations but univalents and quadrivalents in diploid species have also been observed (Melo et al., 2001; Souza, 2002; Souza et al., 2003a). Studies in the interespecific $F_{1}$ hybrids have demonstrated meiotic instability. According to Soares-Scott et al. (2003), there were clear differences in the meiotic behavior between the hybrids, and the sexual hybrid showed more regular meiosis than the somatic hybrid.

Studies on the chiasmata frequency and position are rare in Passiflora. Souza (2002) observed that the mean total number of the chiasmata observed in Passiflora species with $n=6$ was 6.6 while in species with $n=9$ and $n=12$ were 10.5 and 12.1 , consecutively. The recombination index ranged up to $16.49 \%$ among the species with $n=6$ and up to $34 \%$ among the species with $n=9$, while in the species with $n=12$ the variation among species was practically none (only $0.7 \%$ ). The interstitial chiasmata predominated. The meiotic index was below $89 \%$ in $n=12$ species and above $92 \%$ for all the other species studied. The meiotic behavior in the species group with $n=12$ was the only one considered similar due to the approximately 12 chiasmata per cell. Chiasma tended to take place in the interstitial position and MI of approximately $88 \%$. According to Love (1951), the plants with an MI of 90 to $100 \%$ could be considered as stable cytologically, but actually it was impossible to ensure stability in the plants with index of 88 to $92 \%$, since plants with an MI less than $90 \%$ were likely to provide difficulties for the plant breeder in the interspecific crosses.

The pollen viability in the cultivated species has been above $80 \%$ (Barbosa and Vieira, 1997b; Otoni et al., 1995; Souza, 2002; Souza et al., 1998), while in wild species values were observed between 99.5 to $78.2 \%$ (Barbosa and Vieira, 1997a; Ruberté-Torres and Martin, 1974; Souza, 2002). The pollen viability variation was observed in $P$. incarnata, from 55 to $85.3 \%$ during two years of observation (Soares-Scott et al., 2003). According to Souza et al. (2004), it was possible to observe two types of unviable pollen: empty (T1) and shrunken (T2), which could be related to the type of the gene action. A higher T1 pollen percentage (small-sized unviable) in relation to $\mathrm{T} 2$ suggested that meiotic irregularities occurred during the microsporogenesis, were possibly the main cause of the pollen inviability in the Passiflora species analyzed, although post-meiotic genes would also be acting during the microgametogenesis in the passion fruit. Previous meiotic behavior studies in some Passiflora species showed meiotic irregularities to the percentage of unviable pollen (Soares-Scott et al., 1995; Souza et al., 1996; Barbosa and Vieira, 1997a). Abnormally large pollen grains (giant cells, up to $54 \%$ larger than the mean size of normal pollen) were observed in the Passiflora, probably indicating the existence of imbalanced or non-reduced gametes (Souza, 2002).

\section{Nuclear DNA content}

In the last decade, studies using the flow cytometry to obtain nuclear DNA content data have intensified. The genome size in picograms $\left(1 \mathrm{pg}=10^{-12}\right.$; Heslop-Harrison and Schwarzacher, 1996) or megabase pairs ( $1 \mathrm{pg}=980 \mathrm{Mbp}$; Bennett et al., 2000), genome organization (base composition; Dolezel et al., 1992), and ploidy analysis have been obtained by this technique. 
This methodology has been employed because of the precision and the reproducibility of the analysis, easy sample preparation, small quantity of plant material requirement and rapidity in obtaining the results. It

also contributes with plant breeding programs, which involve interspecific hybridization, since in some cases, when parental species have different nuclear DNA content, the flow cytometer may detect interspecific hybrids according to its intermediary DNA values (Keller et al., 1996).

Species of the Passiflora genus present great phenotypic variation, and the few published genome size results show significant differences among the species. Nuclear DNA content was initially determined in pg for $P$. antioquiensis (3.00) using densitometry (Ingle et al., 1975) and $P$. menspermifolia (4.54) using flow cytometry (Arumuganathan and Earle, 1991). Flow cytometry was used to confirm the occurrence of the hybridization and for ploidy determination in $P$. edulis f. flavicarpa $+P$. incarnata somatic hybrids (Otoni et al., 1995). In recent studies, this technique has been shown to be efficient to determine the nuclear DNA content in the Passiflora species (Souza, 2002; Souza et al., 2003b), which present medium genome size (Tabela 2). Only significant interspecific variance has been observed.

\section{CONSIDERATIONS}

In view of the world tendency to eliminate the wild species as a consequence of the deforestation, some Passiflora species are endangered, and genotypes which would be useful for the breeding programs have disappeared. Moreover, cytological studies on the wild species are basic for understanding the chromosome evolution of this genus and the Passifloraceae family. For the plants, including wild and cultivated Passiflora species that are used in the interspecific hybridization, the ability to manipulate meiosis and recombination would have great commercial importance. However, meiosis is a highly dynamic process, and no technique using fixed, dead material will reveal all its subtleties; imaging techniques that can reveal dynamic events in the living organisms are expected to be applied in the near future (Shaw and Moore 1998). Flow cytometry would play an important role in the genetic studies of the Passiflora since species C- values (haploid DNA quantity) might coincide with their crossability relationships (Ohri, 1998) being useful in taxa or genotype selection that would be used in the crosses.

\section{ACKNOWLEDGEMENTS}

Authors are grateful to Prof. Dr. Marcelo Guerra of the Federal University of Pernambuco (PE, Brazil) for the critical reading of this article.

\section{RESUMO}

A família Passifloraceae é representada por espécies de origem tropical e subtropical. Passiflora é o gênero mais rico, com aproximadamente 450 espécies, cerca de 200 delas nativas do Brasil. Recentes estudos cariológicos têm relatado o número básico de cromossomos para o gênero Passiflora como sendo $\mathrm{x}=6$, enquanto $\mathrm{x}=9, \mathrm{x}=10 \mathrm{e} \mathrm{x}=12$ foram considerados números básicos secundários. Altas taxas de fertilidade são observadas na maioria das espécies de Passiflora, uma vez que o índice meiótico e a viabilidade polínica apresentam-se acima de 90\%.Comportamento meiótico irregular tem sido descrito para alguns taxas. Grãos de pólen inviáveis foram observados em espécies diplóides. O tamanho do genoma varia de 1,83 a $5,36 \mathrm{pg}$, e variação interespecífica significativa tem sido observada. Estudos usando a metodologia de hibridização in situ (FISH) tem demonstrado haver de dois a três sites de DNAr $45 \mathrm{~S}$ e um site de DNAr 5S nas espécies analisadas. Nesta revisão, informações sobre os estudos acima mencionados são apresentados e discutidos em detalhes.

\section{REFERENCES}

Arumuganathan, K. and Earle, E. D. (1991), Nuclear DNA content of some important plant species. Plant Mol. Biol. Rep., 9, 208-218.

Bruckner, C. H. (1994), Autoincompatibilidade em maracujazeiro. In: São José, A. R. (Ed.). Maracujá: Produção e Mercado. Universidade Estadual da Bahia, Bahia. pp. 6-18.

Bruckner, C. H.; Casali, V. W. D.; Moraes, C. F.; Regazzi, A. J. and Silva, E. A. M. (1995), Selfincompatibility in passion fruit (Passiflora edulis Sims). Acta Hortic., 370, 45-57. 
Barbosa, L. V. and Vieira, M. L. C. (1997a), Meiotic behavior of passion fruit somatic hybrids, Passiflora edulis f. flavicarpa Degener $+P$. amethystina Mikan. Euphytica, 98, 121-127.

Barbosa, L. V. and Vieira, M. L. C. (1997b), Análise do comportamento meiótico de híbridos somáticos Passiflora edulis f. flavicarpa Degener $+P$. cincinnata Mast. Rev. Bras. Gen., 20, 88 (Suplemento).

Beal, P. R. (1969a), Cytology of the native Australian Passiflora species. 1. Chromosome number and horticultural value. Queensl. J. Agricult. Anim. Sci., 26, 75-81.

Beal, P. R. (1969b), Chromosome numbers of the exotic Passiflora species in Australia. Queensl. J. Agricult. Anim. Sci., 26, 407-421.

Beal, P. R. (1971), Chromosome numbers in some recently introduced species of Passiflora in Australia. Queensl. J. Agricult. Anim. Sci., 28, 179-180.

Beal, P. R. (1973a), Cytology of the native Australian and several exotic Passiflora species. 2. Chromosome morphology. Queensl. J. Agricult. Anim. Sci., 30, 1718.

Beal, P. R. (1973b), Citology of the native australian and several exotic Passiflora species. 3. Morphology of satellited chromosomes. Queensl. J. Agricult. Anim. Sci., 36, 19-24.

Beckett, K. A. (1960), A hybrid passion flower. J. Royal Hortic. Soc., 85, 184-186.

Bennett, M. D.; Bhandol, P. and Leitch, I. J. (2000), Nuclear DNA amounts in angiosperms and their modern uses-807 new estimates. Ann. Bot., 86, 859909.

Benson, W. W.; Brown, K. S. and Gilbert, L. E. (1975), Coevolution of plants and herbivores: passion flower butterflies. Evolution, 29, 659-680.

Bowden, W. M. (1940), The chromosome complement and its evolutionary relationship to cold resistance in the higher plants. Chron. Bot., 6, 123-125.

Bowden, W. M. (1945), A list of chromosome numbers in higher plants. II. Menispermaceae to Verbenaceae. Amer. J. Bot., 32, 191-201.

Chamberlain, C. J. (1932), Methods in plant histology. The University of Chicago Press, Chicago.

Cuco, S. M.; Vieira, M. L. C. and Aguiar-Perecin, M. L. R. (2001), Localização de sítios de rDNA 45S em híbridos somáticos e espécies parentais de Passiflora. Resumos do Congresso Nacional de Genética, 47, Águas de Lindóia, SP: Sociedade Brasileira de Genética, CD Rom.

Darlington, C. D. and Wylie, A. P. (1956), Chromosome Atlas of flowering plants. George Allen and Unwin Ltd., London.

Diers, L. (1961), Der anteil an Polyploiden in den vegetationsgurteln der Westkordillere Perus. Zeitschr. f. Botan., 49, 437-488.
Dolezel, J.; Sgorbati, S. and Lucretti, S. (1992), Comparison of three DNA fluorochromes for flow cytometric estimation of nuclear DNA content in plants. Physiol. Plantarum, 85, 625-631.

Dornelas, M. C.; Tavares, F. C. A.; Oliveira, J. C. and Vieira, M. L. C. (1995), Plant regeneration from protoplast fusion in Passiflora spp. Plant Cell Rep., 15, 106-110.

Fajardo, D.; Angel, F.; Grum, M.; Tohme, J.; Lobo, M.; Roca, W. M. and Sanchez, I. (1998), Genetic variation analysis of the genus Passiflora L. using RAPD markers. Euphytica, 101, 341-347.

Ferreira, F. R. (1994), Germoplasma de Passiflora no Brasil. In: São José, A. R. (Ed.) Maracujá: produção e mercado. UESB, Vitória da Conquista, BA. pp. 2426.

Gill, B. S.; Bir, S. S.; Sikdhuu, M. S. and Singhal, V. K. (1984), Chromosome number reports LXXXIV. Taxon, 33, 536-539.

Greilhuber, J. (1998), Intraspecific variation in genome size: a critical reassessment. Ann. Bot., 82 (Supplement A), 27-35.

Guerra, M. (1986), Citogenética de angiospermas coletadas em Pernambuco, I. Rev. Bras. Gen., 9, 2140.

Harvey, M. J. (1966), IOPB - chromosome number reports VII. Taxon, 15, 155-163.

Heitz, E. (1926), Der nachweis der chromosomen. Vergleichende studien über ihre Zahl, grösse und form im pflanzenreich. I. Zeitschrift für Botanik, 18, 625-681.

Heitz, E. (1927), Pflanzliche chromosomen-zahlen. Tabulae Biologicae, 4, 1-83.

Heslop-Harrison, J. S. and Schwarzacher, T. (1996), Flow cytometry and chromosome sorting. In: Plant chromosomes: laboratory methods. Fukui, K.; Nakayama, S. CRC Press Inc., Flórida. pp. 85-106.

Ingle, J. H.; Timmus, J. N. and Sinclair, J. (1975), Relationship between satellite deoxyribonucleic acid, ribosomal acid gene redundancy, and genome size in plants. Plant Physiol., 55, 496-501.

Janaki Ammal, E. K. (1945), Chromosome atlas of cultivated plants. Darlington, C. D., Janaki Ammal, E. K. (Eds.), George Allen and Unwin Ltd., London. p. 114.

Keller, E. R. J.; Schubert, I.; Fuchs, J. and Meister, A. (1996), Interspecific crosses of onion with distant Allium species and characterization of the presumed hybrids by means of flow cytometry, karyotype analysis and genomic in situ hybridization. Theor. Appl. Gen., 92, 417-424.

Killip, E. P. (1938), The American species of Passifloraceae. Field Museum of Natural History, Bothanical Series 19, Chicago. pp. 7-162. 
Knight, R. J. (1991), Development of tetraploid hybrid passion fruit clones with potencial for the North Temperate zone. HortScience, 26, 1541-1543.

La Cour, L. F. (1951), Annual Report. John Innes Horticultural Institute, 41: 23.

Leitão Filho, H. F. and Aranha, C. (1974), Yellow passion fruit botany. In: Simpósio da cultura do maracujá, 1, Campinas, 1971. Sociedade Brasileira de Fruticultura, Campinas, SP.

Lloyd, R. M. (1963), Tetraploid Passiflora incarnata in North Carolina. Rhodora, 65, 79-80.

Lopes, S. C. (1991), Citogenética do maracujá. In: São José, A. R. (Ed.), A cultura do maracujá no Brasil. Funepe, Jaboticabal. pp. 201-209.

Love, R. M. (1951), Varietal differences in meiotic chromosomes behavior of Brazilian Wheats. Agron. $J ., 43,72-76$.

MacDougal, J. M. (1983) Revision of Passiflora L. section Pseudodysosmia (Harms) Killip emend. J. MacDougal, the hooked trichome group (Passifloraceae). Ph.D. dissertation, Duke University, Durham, North Carolina.

MacDougal, J. M. (2001), Two new species of Passionflower (Passiflora, Passifloraceae) from southwestern Mexico. Novon, 11, 69-75.

Mayeda, L. Y. (1997), Estudo citogenético em dez taxons do gênero Passiflora L. (Passifloraceae). Dissertação de Mestrado, Universidade de São Paulo, Piracicaba, SP, 89p.

Melo, N. F.; Cervi, A. C. and Guerra, M. (2001), Karyology and cytotaxonomy of the genus Passiflora L. (Passifloraceae). Plant Syst. Evol., 226, 69-84.

Melo, N. F. and Guerra, M. (2003), Variability of the 5S and rDNA sites in Passiflora L. with species with distinct base chromosome numbers. Ann. Bot., 92, 309-316.

Nakajima, G. (1931), The chromosome numbers in cultivated and wild Angiosperms. Botan. Mag. (Tokyo), 45, 7-11.

Nishiyama, I. and Kondo, N. (1942), Report of the Kihara Institute for Biological Research, 1. p. 29.

Ohri, D. (1998), Genome size variation and plant systematics. Ann. Bot., 82 (Supplement A), 75-83.

Oliveira, J. C. (1987), Melhoramento Genético. In: Ruggiero, C. (Ed.), Maracujá. Legis Summa, Ribeirão Preto. pp. 218-246.

Oliveira, A. M .A. and Coleman, J. R. (1996), Estudos citogenéticos de espécies do gênero Passiflora (Passifloraceae). Rev. Bras. Gen., 19 (Suplemento), 134.

Otoni, W. C.; Blackhall, N. W.; d'Utra Vaz, F. B.; Casali, V. W. D.; Power, J. B. and Davey, M. R. (1995), Somatic hybridization of the Passiflora species, $P$. edulis f. flavicarpa Degener and $P$. incarnata L. J. Exp. Bot., 46, 777-785.

Passos, I. R. da S. (1999) Comportamento in vitro em Vitis spp. e em Passiflora nitida HBK. Tese de Doutorado. ESALQ-USP, Piracicaba.
Payán, F. R. and Martin, F. W. (1075), Barriers to the hybridization of Passiflora species. Euphytica, 24, 709-716.

Ruberté-Torres, R. and Martin, F. W. (1974), Firstgeneration of edible passion fruit species. Euphytica, 23, 61-70.

Schwarzacher, H. G.; Mikelsaar, A. V. and Schnedl, W. (1980), The nature of Ag-staining of nucleolus organizer regions. Cytog. Cell Gen., 20, 24-39.

Shaw, P. and Moore, G. (1998), Meiosis: vive la difference! Curr. Opin. Plant Biol., 1, 458-462.

Simmonds, N. W. (1954), Chromosome behavior in some tropical plants. Heredity, 8, 139-145.

Simonet, M. and Miedzyrzecki, C. (1932), Étude caryologique de quelques espèces arborescentes ou sarmenteases d'ornement. Comptes-rendus hebdomaires des séances et mémoires de la société de biologie (Paris) III, 40, 969-973.

Snow, N. and MacDougal, J. M. (1993), New chromosome reports in Passiflora (Passifloraceae). Syst. Bot., 18, 261-273.

Soares-Scott, M. D.; Pinto-Maglio, C. A. F.; Rosa, C. and Recco-Pimentel, S. M. (1995), Análise citológica em híbridos interespecíficos de Passiflora. Rev. Bras. Gen., 18 (Suplemento), 427.

Soares-Scott, M. D.; Magnolin, C. A. and ReccoPimentel, S. M. (1999), Análise citogenética e padronização de métodos de isolamento de DNA genômico de espécies e híbridos de Passiflora. Gen. Mol. Biol., 22 (Supplement), 381.

Soares-Scott, M. D.; Meletti, L. M. M.; Bernacci, L. C. and Filho, J. A. (2001), Caracterização de germoplasma de passifloras: $P$. coccinea, $P$. actinea e $P$. ligularis. In: $47^{\circ}$ Congresso Nacional de Genética, SBG, CD Rom.

Soares-Scott, M. D.; Meletti, L. M. M. and ReccoPimentel, S. H. (2003), Meiotic behavior and pollen fertility in sexual and somatic hybrids of Passiflora species. Caryologia, 56, 129-138.

Soares-Scott, M. D.; Meletti, L. M.; Bernacci, L. C. and Passos, I. R. S. (2005), Citogenética clássica e molecular em passifloras. In: Faleiro, F. G.; Junqueira, N. T. V. and Braga, M. F. (Eds.). Maracujá: germoplasma e melhoramento genético. Embrapa Cerrados, Planaltina. pp. 213-240.

Sousa, J. S. I. and Meletti, L. M. M. (1997), Maracujá: espécies, variedades, cultivo. FEALQ, Piracicaba.

Souza, M. M. (2002), Estudos genômico e reprodutivo em espécies de Passiflora. Tese de Doutorado, Universidade Estadual do Norte Fluminense, Campos dos Goytacazes, 162p.

Souza, M. M.; Pereira, T. N. S. and Lam-Sanchez, A. (1996), Meiotic behavior of Passiflora setaceae (Passifloraceae). Rev. Bras. Gen., 19 (Suplemento), 137. 
Souza, M. M.; Pereira, T. N. S.; Martins, E. R. and Borges, E. W. B. (1998), Desenvolvimento e viabilidade do gameta masculino em maracujá amarelo (Passiflora edulis f. flavicarpa Deg.). Gen. Mol. Biol., 21 (Supplement), 170.

Souza, M. M.; Pereira, T. N. S.; Pereira, M. G. and Viana, A. P. (2001), Comportamento meiótico em Passiflora mucronata Lam. e P. giberti N.E. Brown (Passifloraceae). In: $47^{\circ}$ Congresso Nacional de Genética, Sociedade Brasileira de Genética, Águas de Lindóia, CD Rom.

Souza, M. M. and Pereira, T. N. S. and Viana, A. P. and Pereira, M. G. and Bernacci, L. C. and Sudré, C. P. and Silva, L. C. (2003a), Meiotic irregularities and pollen viability in Passiflora edmundoi Sacco (Passifloraceae). Caryologia, 56, 157-165.

Souza, M. M.; Palomino, G.; Pereira, T. N. S.; Pereira, M. G.; Viana, A. P.; Silva, L. C. and Sudré, C. P. (2003b), Variação interespecífica do tamanho do genoma em Passiflora spp. (PASSIFLORACEAE). In: $2^{\circ}$ Congresso Brasileiro de Melhoramento de Plantas, SBMP, Livro eletrônico, 297-302.

Souza, M. M.; Pereira, T. N. S.; Silva, L. C.; Reis, D. S. S. and Sudré, C. P. (2003c), Karyotype of six Passiflora species collected in the state of Rio de Janeiro. Cytologia, 68, 165-171.

Souza, M. M.; Pereira, T. N. S.; Viana, A. P.; Silva, L. C. and Sudré, C. P. (2004), Pollen viability and fertility in wild and cultivated Passiflora species (Passifloraceae). Beitr. Biol. Pflanzen, 73, 359-376.

Souza, M. M.; Pereira, T. N. S.; Dias, A. J. B.; Ribeiro, B. F. R. and Viana, A. P. (2006), Structural, hystochemical and cytochemical characteristics of the stigma and style in Passiflora edulis f. flavicarpa (Passifloraceae). Brazil. Archiv. Biol. Technol., 49, 93-98.
Stebbins, G. L. (1950), Variation and evolution in plants. Columbia University Press, New York.

Storey, W. B. (1950), Chromosome numbers of some species of Passiflora occurring in Hawaii. Pacific Sci., 4, 37-42.

Vanderplank, J. (1991), Passion flowers. Cassel Publishers Limited, London .

Viana, A. P.; Pereira, T. N. S.; Pereira, M. G.; Souza, M. M.; Maldonado, J. F. M. and Amaral Júnior, A. T. (2003), Genetic diversity among yellow passion fruit commercial genotypes and among Passiflora species using RAPD. Rev. Bras. Frutic., 25, 489-493.

Vieira, M. L. C.; Oliveira, C. A.; Mayeda, L. Y.; Dornelas, M. C. and Fungaro, M. H. P. (1997), Estudo do cariótipo e da variabilidade genética detectada por RAPD em espécies de maracujazeiros (Passiflora L.). Rev. Bras. Gen., 20 (Suplemento), 88.

Vieira, M. L. C.; Barbosa, L. V. and Mayeda, L. Y. (2004), Citogenética dos maracujazeiros (Passiflora spp.). In: Lima, A. A., Cunha, M. A. P. (Org.). Maracujá: produção e qualidade na passicultura. EMBRAPA Mandioca e Fruticultura, Cruz das Almas. pp. 45-65.

Vieira, M. L. C. and Carneiro, M. S. (2004), Passiflora spp. Passionfruit. In: Litz, R. (Ed.). Biotechnology of fruit and nut crops. CABI Publishing, Oxfordishire. pp. 436-453. 